\title{
QUALITY OF SERVICES PROVIDED BY SILESIAN HEALTHCARE INSTITUTIONS DURING THE COVID-19 PANDEMIC - RESULTS OF THE SURVEY
}

\author{
Julia JURASIK ${ }^{1}$, Paulina KRĘT ${ }^{2}$, Bartosz ORZEL ${ }^{3 *}$ \\ ${ }^{1}$ Silesian University of Technology, Student Research Club of Quality Management; \\ julijur154@student.polsl.pl, ORCID: 0000-0003-4833-5240 \\ ${ }^{2}$ Silesian University of Technology, Student Research Club of Quality Management; \\ paulkre161@student.polsl.pl, ORCID: 0000-0002-6312-601X \\ ${ }^{3}$ Silesian University of Technology, Faculty of Organization and Management, Department of Economics and \\ Informatics; Bartosz.Orzel@polsl.pl, ORCID: 0000-0003-1506-4798 \\ * Correspondence author
}

Purpose: The purpose of this article is determine the level of medical services quality provided by medical clinics during the COVID-19 pandemic.

Design/methodology/approach: The research was based on analyzing the results of a survey conducted among patients of Silesian clinics. First, a survey sheet was designed using the SERVQUAL model. The next step was to conduct a study in clinics in Silesia. As part of the study, 50 patients' survey votes were received and analyzed.

Findings: Respondents rate the state of health care in Poland as good, telehealth should be reserved for those in quarantine, and should be conducted only when prescriptions are being written, not when diagnosing a patient, respondents pointed out that medical facilities provided meeting conditions that did not expose patients to COVID-19 infection, hence it seems unjustified to use tele advice for patients not under compulsory quarantine.

Research limitations/implications: The main research limitation is the number of feedback surveys received. If there were more votes, the research sample could be even more credible.

Practical implications: The study was conducted in times of a real epidemiological threat. The results of the study show how, in a group of 50 patients, the key aspects related to the provision of medical care in Silesian healthcare institutions are perceived.

Social implications: Patients' observations regarding the functioning of the health care system in times of a pandemic and the key aspects related to ensuring access to this care are extremely valuable tips that may improve the standard of medical care in Poland also during possible future pandemic waves.

Originality/value: Carrying out a literature analysis indicated that there were no studies conducted among patients so far. Thus, the research gap was defined. The authors decided to conduct the study directly among patients by sending the sheets to medical clinics.

Keywords: COVID-19, Quality of medical services, Pandemic, Medical Services, Quality.

Category of the paper: Research paper. 


\section{Introduction and literature review}

The approach to the quality of medical services provided by health care clinics has changed significantly during the pandemic. Both the method of providing medical services and access to a general practitioner have been significantly limited. The most affected group of patients seems to be those who are constantly under medical care, require longer treatment, and are chronically ill. Due to the epidemiological threat, the approach to issues related to the availability of general practitioners and specialist clinics has also changed. The publication proposed and implemented a solution based on the use of the SERVQUAL model to test the expectations and the degree of patient satisfaction with the medical services received during the pandemic. Based on the analyzed literature, a research gap in this area was found. 10 publications, both Polish and international, on the subject of researching the quality of providing medical services during the COVID-19 pandemic were taken into account (Piasecki, 2020; Kryvachuk, 2020; Sadoch, 2021; Pylińska-Dąbrowska, 2021; Szymańska, 2020; Kopeć, 2021; Drozd, Bułaś, 2021; Obrębski et al., 2021; Robakowski, Synowiec, 2021; Krzystanek et al., 2020). The literature review allowed not only to identify the research gap but also helped to establish the research method consisting in conducting a survey-based fully on the concept of the SERVQUAL model.

Analyzing the topic of the quality of services in times of a pandemic, most publications concern the quality of education, the impact of the pandemic on the quality of work, and employee satisfaction with its performance in various industries. Analyzed publications (Theoret, Ming, 2020; Al-Samarrai et al., 2020; Sarkar, 2020; Onyema et al., 2020). The results of the analyzed publications indicate the negative impact of the coronavirus on the quality of education. According to the results of the research, the very process of education may be disturbed, however, equally serious effects may affect the students and teachers participating in the process. The publications highlighted the malaise of students participating in the remote education process. Often the very process of isolated learning may be detrimental to young people whose natural need is contact with the environment and surroundings (Onyema et al., 2020). Other studies indicate remote learning difficulties hitting underdeveloped or early economic development countries (Al-Samarrai et al., 2020). This state of affairs can easily be related to the functioning of other sectors and the differences between highly developed and less developed countries. Research on the coping of health services during a pandemic in underdeveloped countries shows that the quality of medical services is declining. It is more felt for patients than in highly developed countries (Paital, Parida, 2020; Khan et al., 2020; Jiang et al., 2021).

When looking at the quality of ensuring the quality of medical services provided by medical facilities in Poland in the times of the covid-19 pandemic, it is also worth looking at the issue of securing and job satisfaction among healthcare workers. The conducted research indicates 
a fairly good level of satisfaction with the work with the use of personal protection measures by Polish doctors. It is also worth mentioning that doctors are provided with adequate amounts of personal protective equipment in times of a pandemic. Unfortunately, the situation in Poland is worse in the area of informing about the possibility of infectious or viral diseases or cases of its occurrence among health care workers. Individual zones in hospitals are also not properly designated. There are also deficiencies in training and informing employees about the epidemic situation in health care facilities, which are places of particular risk of infectious and viral diseases (Orzeł, Wolniak, 2021; Orzeł, Horodecka, 2021). On the other hand, to improve the flow of information and facilitate the proper redistribution of personal protective equipment in certain countries (e.g. Denmark), the obligation to prepare reports on the availability of masks, disinfectants, and gloves on the market has been introduced (Furman et al., 2020). From the patient's point of view, satisfaction with services may depend on the clarity of information found on the clinic's website. Especially in the noise of information coming about the pandemic situation. In the era of widespread isolation, electronic services and medical services, in which patients search for phrases about health care, disease symptoms, and safety, are gaining in importance. In the era of a pandemic, the inflow of information, up-to-date information, and its clarity are important, not only directly provided services (Król et al., 2021). However, the latter should not be underestimated either. Research shows that the emotional value - appreciation, care for the patient, empathic disposition - affects his satisfaction, and then loyalty to a given medical facility (Akob et al., 2021). According to the research, in the eyes of doctors, computerization - e-prescriptions, electronic medical documentation is a positive change in the healthcare system. This shows that in addition to medical personnel, technical and IT personnel is important elements of the hospital ecosystem (Haberla, 2021; Król et al., 2021). On the other hand, technologically excluded people deepen their confusion in the age of computerization and prefer a personal consultation with a doctor (Kaźmierczak, 2020). However, computerization may, in the long run, reduce the exclusion of rural inhabitants in Poland (Wójcik, 2020). Data from March 2020 indicated that many people were underestimating the uniqueness of the pandemic (Poczucie, 2020). It turned out, however, that the pandemic revealed a multitude of differences in the level of efficiency of health care systems in European countries, despite the use of similar strategies of coping with it - limiting the activities of many areas of public life. The shortage of personal protective equipment and the lack of equipment in hospitals became a common problem, with which, for example, Belgium tried to cope by limiting access to them only to medical facilities.

In Poland, the public procurement procedure has been simplified to speed up and streamline the process of acquiring PPE. However, prices for protective measures were not lowered, as was the case, for example, in Bulgaria or France. These actions led to a series of abuses, which were presented by the Polish Ministry of Health (Furman et al., 2020). Human resources are a key component of the tools to fight the COVID-19 virus. Information collected from European countries showed that the unexpected situation forced them to undertake many 
non-standard actions. In some countries, the beginning of the pandemic was marked by a drastic decrease in the availability of medical services, which at its peak even led to the selection of patients depending on their age and health status, and on its basis, the decision to assist was made. It is caused by low expenditures on the health service in Poland, shortage of medical equipment (including respirators), insufficient hospitals (Haberla, 2021), and shortages of human resources in the health service, which are one of the largest in Europe - the number of doctors and nurses per 1000 people is 2.3 and 5.2, respectively (Libura et al., 2018; Wójcik, 2020). Most European countries, including Poland, have agreed to involve medical students in the fight against the pandemic, as well as additional medical professionals (Furman et al., 2020). However, one of the authors noted the unlawfulness of the decision on the refusal to provide medical services by doctors, in the face of the unconfirmed risk of the patient becoming infected with the COVID-19 virus, referring to the ideals of medical ethics, according to which the patient's interest should take precedence over the interest of the doctor (Piasecki, 2020). These shortages and chaotic decisions led to the extension of the usually long queues to specialist doctors, breaks in diagnostics, and disturbances in the way of communication, primary care physician - specialist physician (Haberla, 2021). The SERVQUAL method has already been used to examine patients' expectations and opinions on the quality of care they receive in Polish medical facilities.

The conducted research and the obtained results show that using the SERVQUAL method it is possible to locate the features of the service that are perceived by patients as not fully meeting their expectations and those that are at a satisfactory level. (Lewandowski, 2008). Since SERVQUAL is a tool that allows examining the subjective feelings of the patient, the authors of this study decided to use them in the framework of the research, the results of which are presented later in the article.

\section{The survey sheet - design and methods}

There are many methods of measuring service compliance presented in the literature. The SERVQUAL (Service Quality) method allows you to monitor the level of customer satisfaction with the service received against the previously set expectations. Others are, for example, the SERVPERF method, which in turn assumes that the service provided has the only impact on quality. The subjective opinion of the respondent is not taken into account, which in the case of medical services that rarely provide unambiguous results (talking about a "healthy" or "sick" patient at the exit) seems unjustified. Patient satisfaction in this case concerns the immeasurable value of life, therefore it is impossible to depict it in the form of framework features of the service. On the other hand, the Critical Incidents Method (CIT) or the analysis of complaints are open methods (open interview), with regard to which it is more 
difficult to compile customer reviews in a numerical scale and provides only descriptions of extreme sensations. The methods of assessing the quality of services presented above constitute only a part of the methods developed in this area. Each of them has undoubted advantages, but also disadvantages. The SERVQUAL method is based on the concept of customer learning people get to know what they like and what they do not like for the service provided. The SERVQUAL method works effectively when used in combination with socialization and self-determination theory. Although this method was originally used to test the quality of services in the banking sector, the very fact of comparing the expectations with the current state makes it a useful tool in the context of the problem under consideration. The 5-point satisfaction scale that was used allows for a fairly accurate statement of the patient's satisfaction level and its average level.

The questionnaire was constructed based on the SERVQUAL method. The form of questions related to patient satisfaction, their expectations, and observations in relation to medical clinics as well as hospitals was used. The respondents to the survey were patients of family clinics from the area of Upper Silesia, the selection was random.

The first part of the survey included general questions about whether or not to be a GP patient during the COVID-19 pandemic, the possible number of appointments, and general opinion on the functioning of the healthcare system during the pandemic. In the case of the last question, a five-point scale was used, where "1" means "very bad" and "5" means "very good" (Table 1).

Table 1.

Introductory questions regarding exposure to medical facilities during a pandemic and general opinion on medical services provided during a pandemic

\begin{tabular}{|c|c|c|c|c|c|}
\hline \multicolumn{6}{|c|}{ Please put $X$ in the appropriate box or select the appropriate answer } \\
\hline \multicolumn{6}{|l|}{ I was GP patient during the COVID-19 pandemic } \\
\hline \multicolumn{6}{|l|}{ During the COVID-19 pandemic, I was not family doctor patient } \\
\hline During the pandemic, I was a GP patient: & & & $\begin{array}{l}\text { tin } \\
\text { tin } \\
\text { tin } \\
\text { tin } \\
\text { nor }\end{array}$ & $\begin{array}{l}S \\
S\end{array}$ & \\
\hline $\begin{array}{l}\text { I rate the functioning of the health service in times of a pandemic on a scale of 1-5, } \\
\text { where } 1 \text { is very bad and } 5 \text { is very good (please tick) }\end{array}$ & 1 & 2 & 3 & 4 & 5 \\
\hline
\end{tabular}

Source: own work based on SERVQUAL Method.

In part 2 of the questionnaire, a five-point Likert scale was used, in which, depending on the question category, 5 points were awarded for high or low satisfaction/agreement with the given statement. The first pool of questions concerned people who were patients of family medicine clinics during the pandemic and was aimed at examining the level of satisfaction of these people with the visit, where "1" meant satisfaction at a "very poor" level, and "5" meant high satisfaction with services (Table 2). 
Table 2.

Questions related to patient satisfaction with the basic characteristics of a visit to a medical clinic

\begin{tabular}{|c|c|c|c|c|c|}
\hline & Very low & & & & Very high \\
\hline $\begin{array}{l}\text { 1/ I am satisfied with the last visit provided by the } \\
\text { family clinic during COVID-19 to the extent of: }\end{array}$ & 1 & 2 & 3 & 4 & 5 \\
\hline $\begin{array}{l}\text { 2/ I describe my level of satisfacion with the contact } \\
\text { with a family doctor (first contact doctor) as: }\end{array}$ & 1 & 2 & 3 & 4 & 5 \\
\hline $\begin{array}{l}3 \text { / I describe my level of satisfacion with the speed } \\
\text { of the visit to the health center as: }\end{array}$ & 1 & 2 & 3 & 4 & 5 \\
\hline $\begin{array}{l}\text { 4/ I describe my satisfacion with the medical } \\
\text { advice as: }\end{array}$ & 1 & 2 & 3 & 4 & 5 \\
\hline
\end{tabular}

Source: own work based on SERVQUAL Method.

The next part of the questionnaire was an analysis of the expectations of patients in relation to medical clinics, which were born with the outbreak of the pandemic and changes in the functioning of the Polish health care system. They referred to the priority in access to medical services provided to some people (patient categorization), as well as COVID-19 tests and the extent to which patients care about introducing or continuing these changes. Some examples are shown below (Table 3).

Table 3.

Questions examining patients' expectations towards the activities of medical clinics

\begin{tabular}{|c|c|c|c|c|c|}
\hline & $\begin{array}{l}\text { I do not } \\
\text { care }\end{array}$ & & & & $\begin{array}{l}\text { I care } \\
\text { a lot }\end{array}$ \\
\hline $\begin{array}{l}\text { 1/ Patients should visit their doctor safely, so as not } \\
\text { to expose them to the possibility of contracting an } \\
\text { infectious or viral disease. }\end{array}$ & 1 & 2 & 3 & 4 & 5 \\
\hline $\begin{array}{l}\text { 2/ Access to prescription drugs should be greatly } \\
\text { facilitated in times of the COVID-19 pandemic. }\end{array}$ & 1 & 2 & 3 & 4 & 5 \\
\hline $\begin{array}{l}\text { 3/ Tele-advice provided by GPs should only be } \\
\text { reserved for those in isolation/quarantine or } \\
\text { suspected COVID-19 infection. }\end{array}$ & 1 & 2 & 3 & 4 & 5 \\
\hline $\begin{array}{l}\text { 4/ Tele-advice should be conducted only in the case } \\
\text { of prescribing, and not for diagnosing a patient. }\end{array}$ & 1 & 2 & 3 & 4 & 5 \\
\hline $\begin{array}{l}\text { 5/ Patients in quarantine/isolation should have } \\
\text { priority access to GP advice. }\end{array}$ & 1 & 2 & 3 & 4 & 5 \\
\hline $\begin{array}{l}\text { 6/ People over } 60 \text { years of age should have priority } \\
\text { access to a general practitioner. }\end{array}$ & 1 & 2 & 3 & 4 & 5 \\
\hline $\begin{array}{l}\text { 7/ All patients should be treated the same regardless } \\
\text { of age, presence of comorbidities, etc. }\end{array}$ & 1 & 2 & 3 & 4 & 5 \\
\hline $\begin{array}{l}\text { 8/ First aid should be provided reagrdless of the } \\
\text { COVID-19 test result. }\end{array}$ & 1 & 2 & 3 & 4 & 5 \\
\hline
\end{tabular}

Source: own work based on SERVQUAL Method.

The fourth set of questions illustrated the current situation in clinics and medical centers. The respondents could determine to what extent the given statements are (5 points) or not (1 point) true (Table 4). 
Table 4.

Statements about the situation in health care clinics

\begin{tabular}{|c|c|c|c|c|c|}
\hline & Not true & & & & True \\
\hline $\begin{array}{l}1 / \text { Patients are seen in person by a general } \\
\text { practitioner. }\end{array}$ & 1 & 2 & 3 & 4 & 5 \\
\hline $\begin{array}{l}\text { 2/ Patients are seen by a doctor in a safe manner (in } \\
\text { a way that does not expose them to infection). }\end{array}$ & 1 & 2 & 3 & 4 & 5 \\
\hline $\begin{array}{l}\text { 3/ Access to medicines in times of a pandemic in } \\
\text { much easier. }\end{array}$ & 1 & 2 & 3 & 4 & 5 \\
\hline $\begin{array}{l}\text { 4/ Tele-advice is only provided for people in } \\
\text { quarantine/home isolation. }\end{array}$ & 1 & 2 & 3 & 4 & 5 \\
\hline $\begin{array}{l}5 / \text { Tele-advice is for the sole purpose of prescribing } \\
\text { a prescriprion and not for diagnosing a patient. }\end{array}$ & 1 & 2 & 3 & 4 & 5 \\
\hline $\begin{array}{l}\text { 6/ Patients in quarantine/home isolation have } \\
\text { priority access to their GP. }\end{array}$ & 1 & 2 & 3 & 4 & 5 \\
\hline $\begin{array}{l}\text { 7/ All patients are treated the same regardless of age, } \\
\text { presence of comorbidities, etc. }\end{array}$ & 1 & 2 & 3 & 4 & 5 \\
\hline $\begin{array}{l}\text { 8/ First aid is given regardless of the COVID-19 test } \\
\text { result. }\end{array}$ & 1 & 2 & 3 & 4 & 5 \\
\hline
\end{tabular}

Source: own work based on SERVQUAL Method.

The next 13 questions concerned observations in relation to the work of medical clinics and were a kind of development of the previous category with the general situation in the Polish health service, and thus often controversial behavior towards the patient. The respondents had the opportunity to determine the degree to which they agreed with a given observation. Some of the statements are presented in Table 5.

Table 5.

Statements about phenomena in healthcare since the outbreak of the pandemic

\begin{tabular}{|c|c|c|c|c|c|}
\hline & \multicolumn{3}{|c|}{ I strongly agree } & \multicolumn{2}{|c|}{ I strongly disagree } \\
\hline $\begin{array}{l}\text { 1/ Patients have limited access to medical advice during the } \\
\text { COVID-19 pandemic. }\end{array}$ & 1 & 2 & 3 & 4 & 5 \\
\hline $\begin{array}{l}\text { 2/ There is a problem with obtaining a prescription for } \\
\text { medications prescribed by a general practitioner. }\end{array}$ & 1 & 2 & 3 & 4 & 5 \\
\hline $\begin{array}{l}3 \text { / There is a problem with obtaining a prescription for } \\
\text { medications prescribed by a specialist doctor. }\end{array}$ & 1 & 2 & 3 & 4 & 5 \\
\hline $\begin{array}{l}\text { 4/ There is a problem with consultation/obtaining a referral for } \\
\text { a test in the case of suspected COVID-19 infection. }\end{array}$ & 1 & 2 & 3 & 4 & 5 \\
\hline $\begin{array}{l}5 / \text { There is a problem with getting a referral to a specialist } \\
\text { doctor from a general practitioner. }\end{array}$ & 1 & 2 & 3 & 4 & 5 \\
\hline $\begin{array}{l}\text { 6/ The COVID-19 pandemic has drastically worsened the } \\
\text { outlook for the quality of medical services provided to } \\
\text { chronically ill people. }\end{array}$ & 1 & 2 & 3 & 4 & 5 \\
\hline $\begin{array}{l}\text { 7/ I have concerns about the functioning of the health care } \\
\text { system in Poland as the duration of the COVID-19 pandemic } \\
\text { increases. }\end{array}$ & 1 & 2 & 3 & 4 & 5 \\
\hline $\begin{array}{l}\text { 8/ The waiting time for assistance in the hospital emergency } \\
\text { room was significantly extended. }\end{array}$ & 1 & 2 & 3 & 4 & 5 \\
\hline $\begin{array}{l}\text { 9/ The waiting time for the arrival of an ambulance was } \\
\text { extended due to the lack of information about the patient's } \\
\text { infection. }\end{array}$ & 1 & 2 & 3 & 4 & 5 \\
\hline $\begin{array}{l}\text { 10/ Due to the uncertainty of the staff related to the possibility } \\
\text { of contact with a patient infected eith COVID-19, the waiting } \\
\text { time for providing emergency medical care was extended. }\end{array}$ & 1 & 2 & 3 & 4 & 5 \\
\hline
\end{tabular}

Source: own work based on SERVQUAL Method. 
The last part of the questionnaire was intended to trace the characteristics of medical services that patients consider to be key. Among the potentially significant attributes are the speed of actions taken, the availability of doctors and medical assistance, and the safety of visits (Table 6).

Table 6.

Questions on the key features ensuring the quality of services provided by medical clinics

\begin{tabular}{|c|c|c|c|c|c|}
\hline & Irrelevant & & & & ortant \\
\hline 1/ The speed of obtaining medical advice. & 1 & 2 & 3 & 4 & 5 \\
\hline $\begin{array}{l}\text { 2/ Ease of access to prescriptions and prescription } \\
\text { drugs. }\end{array}$ & 1 & 2 & 3 & 4 & 5 \\
\hline 3/ Minimizing the risk COVID-19 infection. & 1 & 2 & 3 & 4 & 5 \\
\hline $\begin{array}{l}\text { 4/ Speed of obtaining referral to specialist doctors } \\
\text { and further diagnostics. }\end{array}$ & 1 & 2 & 3 & 4 & 5 \\
\hline $\begin{array}{l}\text { 5/ Access and speed of consultation and referral for } \\
\text { a tesr in the case of suspected COVID-19 infection. }\end{array}$ & 1 & 2 & 3 & 4 & 5 \\
\hline $\begin{array}{l}\text { 6/ Access to medical assistance that does not require } \\
\text { hospitalization. }\end{array}$ & 1 & 2 & 3 & 4 & 5 \\
\hline $\begin{array}{l}\text { 7/ Access to medical aid, including respirators, } \\
\text { regardless of the patient's age and coexisting } \\
\text { diseases. }\end{array}$ & 1 & 2 & 3 & 4 & 5 \\
\hline
\end{tabular}

Source: own work based on SERVQUAL Method.

\section{Results}

A total of 50 people participated in the survey, of which 15 people marked the gender "female" and 10 people marked "male." The remaining individuals did not provide an answer about their gender. Of the total respondents, only 25 people answered about their age. Under $20-0$ respondents, between 20 and 30 years old -3 respondents, between 30 and 40 years old -7 respondents, between 40 and 50 years old -6 respondents, and over 50 years old -9 respondents. There were 25 responses regarding the respondents' education 14 respondents said they had a high school education, 11 respondents said they had a college education, and no one indicated they had only primary education. Most respondents mentioned Świętochłowice (38 responses), followed by Zabrze (4 respondents), Gliwice (1), Tarnowskie Góry (1 respondent), Katowice (2) and Chorzów (4).

As many as 41 out of 50 respondents answered that they were a patient of their family doctor during the pandemic. Moreover, the frequency of these visits according to the collected responses was as follows: 1 time accounted for $29 \%$ of responses, 2 times was $24 \%$, while 3 times was $22 \%$, and 4 times and 5 or more times were $12 \%$ each. When asked to rate the functioning of the health service during the pandemic, respondents most often chose the rating $3(34 \%)$, followed by rating 4 (23\%), ratings 1 and 5 received the same number of votes (15\% each), and rating 2 was chosen the least often (13\%). Thus, it can be concluded that the 
overall assessment of health care during the pandemic is average, but leans nonetheless towards a good rating.

Among respondents, satisfaction with medical care is overwhelmingly positive. In one question about satisfaction with the last visit, the highest rating was 5 - very good (43\%). Satisfaction with doctor contact was rated similarly high, with the highest score receiving 26 votes $(59 \%)$. Also, the speed of the visit, i.e. waiting time for the visit, according to the respondents' answers, was rated overwhelmingly positive. The survey also shows that the medical advice received met the expectations of the respondents.

The most important expectations of patients about the outpatient clinic include personal visits with a general practitioner (48\% definitely yes), carrying out medical visits in a safe manner, i.e. not exposing patients to infection (71\%), and easy access to prescription drugs $(68 \%)$. In addition, more than half of respondents indicated that telehealth should be reserved for those in quarantine, and should be conducted only when prescriptions are being written, not when diagnosing a patient. Another of the respondents' expectations was that health centers should be able to test for COVID-19 (more than half of the votes). Respondents also felt that patients in isolation or quarantine and those over the age of 60 were more likely to have priority access to a primary care physician, but equally high marks were given to the statement that all patients should be treated the same regardless of age or presence of comorbidities. Respondents unanimously agreed that first aid should be provided regardless of COVID-19 test results (93\% definitely yes).

The current situation in health care clinics is assessed rather well. Nearly half of the respondents $(57 \%)$ state that patients are seen in person by a general practitioner and access to prescription drugs during a pandemic is facilitated. According to the responses collected, the way patients are admitted does not put them at risk of infection, but voices are divided on the issue of equal treatment. It can be said that the expectations of the respondents are consistent with the present situation.

Observations about clinic services during the COVID-19 pandemic tended to suggest that patients are unlikely to have limited access to medical advice and that there is little risk of infection during a face-to-face visit to a doctor. Furthermore, it was felt that there are unlikely to be problems in obtaining prescriptions from both GPs and specialists, and there are no major problems in obtaining consultations and referrals when COVID-19 infection is suspected. However, it was pointed out that there may be some problems in obtaining referrals to specialists from GPs. It was unanimously assessed that people over 60 years of age do not have a problem accessing a doctor and there is no problem in obtaining emergency care. The survey also shows that according to the respondents, the COVID-19 pandemic did not drastically affect the deterioration of the quality of life, and concerns about the functioning of the healthcare system in Poland are not significant, but according to the assessments, the waiting time for the arrival of an ambulance and first aid in the hospital emergency room has rather increased. 
The following were considered crucial for the quality of medical services provided by outpatient clinics: speed of obtaining medical advice, ease of direct access to a general practitioner and prescriptions and prescription drugs, minimizing the risk of COVID-19 infection, speed of obtaining referrals and availability of consultations in case of suspected infection, access to medical assistance (which does not require hospitalization), and access to medical assistance including ventilators regardless of the patient's age and coexisting diseases.

\section{Conclusions}

In summary, it can be said that the respondents rate the state of health care in Poland as good, they did not perceive significant problems with access to telemedicine and visits to general practitioners or specialists as well as with obtaining and filling prescriptions. However, the survey found that the waiting time for an ambulance to arrive and the response time of emergency medical services have increased. Respondents' voices are divided when it comes to priority access to a general practitioner for people with comorbidities, those over 60 and those in quarantine or home isolation. Respondents also believe that currently all patients tend to be treated equally regardless of diseases and conditions, age, or being in quarantine or home isolation. Thus, it can be concluded that all respondents expect to be assured of equal treatment by the health service in accessing medical services and that clinics maintain high availability and quality of medical services despite the COVID-19 pandemic. With the pandemic, anxiety about health and the future has undoubtedly increased in many people, which reduces mental well-being. It is understandable that every patient expects that if they observe symptoms of COVID-19 disease, they will receive professional help quickly enough. $57 \%$ of patients who had a chance to see a doctor directly are still too small a number to speak of unwavering behavior in the functioning of the Polish health service. Referring to the noticeable trends in unequal treatment of patients, it can be concluded that the remaining $43 \%$ are patients who were refused direct advice. This phenomenon, combined with extended waiting times for first aid or the arrival of an ambulance, can significantly increase patient mortality due to the so-called comorbidities that were ignored for fear of potential COVID-19 infection. One might be tempted to say that the pandemic itself, the virus that caused the pandemic, does not threaten us as much as the side effects it entails. We are talking about the growing importance of online medical services, online diagnostics, which lead to a decrease in the detection of potentially more lethal diseases than COVID-19, e.g. cancers, or delays in starting their treatment. The respondents pointed out that medical facilities provided meeting conditions that did not expose patients to COVID-19 infection, hence it seems unjustified to use tele advice for patients not under compulsory quarantine. The respondents' answers also show that the speed of medical assistance provided during a pandemic is more important to them than protection against virus infection. Therefore, it seems that the only solution improving the functioning of the Polish 
health care system is the recognition that every patient, regardless of age or coexisting diseases, deserves equal help. It is worth paying attention to the results of the research in the context of previous work carried out as part of projects on satisfaction with the functioning of the health service during a pandemic. From the point of view of the results of the study, the publications on the satisfaction of health care workers with personal protective equipment are important. The results of the publications, which were written by Orzeł, B., Horodecka A.M. and Orzeł, B., Wolniak, R. (Orzeł, Horodecka, 2020; Orzeł, and Wolniak, 2021) show that specialists dealing with patient care in Poland are also rather satisfied with the personal protective equipment offered to them. . As in the case of patients, the biggest problem concerns soft aspects in medical facilities such as information, appropriate allocation of places, facilities, etc. Thus, on the basis of the surveyed sample and data analysis, it can be concluded that the hard aspects of medical care in Poland, such as access to a doctor, access to personal protection measures, the sense of security are at the appropriate level to be able to provide basic medical care even in times of a pandemic.

Thinking in the context of future research on the phenomenon of satisfaction, it would be worth conducting a similar study among patients referring to specific specialist doctors. Perhaps, then their opinions would differ from the opinions of patients referring to general practitioners presented in this publication. It is also worth considering conducting a similar study in a larger number of patients.

\section{Acknowledgements}

This article was published from the funds granted to the Student Quality Management Association as part of the Inicjatywa Doskonałości - Uczelnia Badawcza project and is a presentation of the results of the research carried out as part of the project "Badanie Poziomu Jakości Świadczenia Usług Medycznych w Śląskich Przychodniach w Czasach Pandemii COVID-19".

\section{References}

1. Akob, M., Yantahin, M., Ilyas, G.B., Hala, Y., Putra, A.H.P.K. (2021). Element of Marketing: SERVQUAL Toward Patient Loyalty in the Private Hospital Sector. The Journal of Asian Finance, Economics and Business, 8(1), 419-430

2. Al-Samarrai, S., Gangwar, M., \& Gala, P. (2020). The impact of the COVID-19 pandemic on education financing. 
3. Centrum Badań Opinii Społecznej (2020). Poczucie zagrożenia u progu epidemii koronawirusa, vol. 40.

4. Drozd, M., \& Bułaś, L. (2020). Czy nieprawidłowości w aptekach ogólnodostępnych stwierdzone podczas kontroli Inspekcji Farmaceutycznej mogą być miarą jakości usług farmaceutycznych? cz. 1. Analiza ogólna. Farmacja Polska, 76(6), 307-311.

5. Furman, M., Kowalska-Bobko, I., Sowada, C. (2020). Activities of public health authorities to combat COVID-19 in selected European countries. Public Health and Management, $18(2), 176-184$.

6. Haberla, M. (2021). Problems of the health care system and barriers to cooperation between the primary care physician and the specialist in the light of qualitative research. Marketing research against new trends in the environment, 183.

7. Jiang, P., Klemeš, J.J., Fan, Y.V., Fu, X., \& Bee, Y.M. (2021). More is not enough: A deeper understanding of the COVID-19 impacts on healthcare, energy and environment is crucial. International Journal of Environmental Research and Public Health, 18(2), 684.

8. Kaźmierczak, J., Bartnicka, J., Borgosz, G., Ikem, B., Jurasik, J., Kręt, P., Pietrulińska, N., Radomski, M. (2020). Developing the Cognitive Abilities of Elferly People with the Use of IT Technologies: Presentation of the Project Assumptions and Description of the Research Concept. Multidisciplinary Ascpect of Production Engineering, 3(1), 505-516

9. Khan, S., Siddique, R., Ali, A., Bai, Q., Li, Z., Li, H., ... \& Nabi, G. (2020). The spread of novel coronavirus has created an alarming situation worldwide. Journal of infection and public health, 13(4), 469.

10. Kopeć, Z. (2021). Dobrostan pary w trakcie pandemii COVID-19 a decyzje prokreacyjne.

11. Król, K., Zdonek, D. (2021). The Quality of Infectious Disease Hospital Websites in Poland in Light of the COVID-19 Pandemic. Environmental Research and Public Health, 18(2), 642.

12. Kryvachuk, L. Usługi społeczne dla dzieci i młodzieży w czasie pandemii COVID-19 na Ukrainie Social services for children and youth during the COVID-19 pandemic in Ukraine. Wyzwania dla polityki społecznej w kontekście pandemii koronawirusa, 173.

13. Krzystanek, M., Matuszczyk, M., Krupka-Matuszczyk, I., Koźmin-Burzyńska, A., Segiet, S., \& Przybyło, J. (2020). Telewizyta (e-wizyta) na czas kryzysu epidemicznego rekomendacje w zakresie prowadzenia wizyt online w opiece psychiatrycznej. Psychiatria, 17(2), 61-65.

14. Lewandowski, R. (2008). Measurement of the quality of medical services using the SERVQUAL method. Quality Problems, 9, 30-35

15. Libura, M., Greser, J., Borek, E., Perendyk, T., Sitek, A., Wojtaszczyk, K. (2018). Financing and organization of the health care system in the eyes of patients, 22-44.

16. Obrębski, J., Skorek, P., Tretiakow, D., Narożny, W., \& Skorek, A. (2021). Pacjent $\mathrm{w}$ gabinecie otolaryngologicznym $\mathrm{w}$ dobie pandemii COVID-19 w świetle aktualnych wytycznych, przepisów prawnych i własnych doświadczeń. Medycyna Pracy, 72(3). 
17. Onyema, E.M., Eucheria, N.C., Obafemi, F.A., Sen, S., Atonye, F.G., Sharma, A., \& Alsayed, A.O. (2020). Impact of Coronavirus pandemic on education. Journal of Education and Practice, 11(13), 108-121.

18. Orzel, B., \& Horodecka, A.M. (2021). The adoption of SERVQUAL method to analyze the quality assurance factors of personal protective equipment for healthcare workers. Zeszyty Naukowe Politechniki Ślaskiej, Seria: Organizacja i Zarządzanie, 151, 501-511.

19. Orzeł, B., \& Wolniak, R. (2021). Clusters of Elements for Quality Assurance of Health Worker Protection Measures in Times of COVID-19 Pandemic. Administrative Sciences, 11(2), 46.

20. Paital, B., Das, K., \& Parida, S.K. (2020). Inter nation social lockdown versus medical care against COVID-19, a mild environmental insight with special reference to India. Science of the total environment, $728,138914$.

21. Piasecki, J. (2020). Obowiązek wykonywania świadczeń w czasie epidemii. Filozofia w Praktyce, vol. 6.

22. Pylińska-Dąbrowska, D. (2021). Ocena nasilenia lęku związanego z zabiegami z zakresu chirurgii stomatologicznej $w$ trakcie trwania pandemii COVID-19 (Doctoral dissertation).

23. Robakowski, P., \& Synoweć, J. (2020). Polityka zdrowotna RP - co zmieniło się w dobie COVID-19. Studia Polityczne, 48(3), 85-106.

24. Sadoch, M. (2021). Ocena jakości usług edukacyjnych na przykładzie firmy SuperBystrzak.

25. Sruthi, N., Kuppuswamy, G., \& Vignesh, M. (2020). An epitome of the healthcare system in underdeveloped countries concern with COVID-19. International Journal of Pharmaceutical Research, 13(1).

26. Szymańska, M. Sytuacja Pacjentów z przewlekta obturacyjna choroba płuc $w$ dobie pandemii COVID-19.

27. Tarkar, P. (2020). Impact of COVID-19 pandemic on education system. International Journal of Advanced Science and Technology, 29(9s), 3812-3814.

28. Theoret, C., \& Ming, X. (2020). Our education, our concerns: The impact on medical student education of COVID-19. Medical Education, 54(7), 591-592.

29. Wójcik, M. (2020). Comparative analysis of the state of health care in voivodeships. Quantitative Methods In Economic Studies, 21(1), 39-49. 